\title{
A Final Word
}

The willingness of all those involved to spend time putting this tribute to Ryuichi together reflects the enormous respect, and love, those around the world who were fortunate enough to know Ryuichi, to work with Ryuichi, to be mentored by Ryuichi have for this great man.

To have worked with Ryuichi in his role as an Editor of Transportation was a real privilege.

Ryuichi's impact on research and practice as well as on the careers of very many is truly remarkable, as was the courage and optimism with which he faced his fight against cancer.

I am sure that this issue of Transportation is a very fitting tribute to Ryuichi, and I am very grateful to all those who have made it possible, particularly to Pat Mokhtarian and Kay Axhausen who have done so much of the work.

Martin Richards

Editor in Chief 